\title{
Analysis of Network Model Determinant on Tourism SMEs Performance
}

\author{
Rochiyati Murniningsih ${ }^{1 *}$, Yulinda Devi Pramita ${ }^{2}$, Friztina Anisa $^{1}$, Eni Zuhriyah ${ }^{1}$
}

\author{
${ }^{1}$ Department of Management, Universitas Muhammadiyah Magelang, Magelang, Indonesia \\ ${ }^{2}$ Department of Accounting, Universitas Muhammadiyah Magelang, Magelang, Indonesia \\ *Corresponding author. Email: rochiyati.murni@ummgl.ac.id
}

\begin{abstract}
This research empirically tests and analyzes the network model that affects the performance of Tourism SMEs. The SME Tourism network model includes knowledge sharing and innovation. Knowledge sharing is measured by network density, network centrality, relational social capital (CSR) and cognitive social capital. The model was developed based on the relationship between tourism SMEs through one-cluster SME networks, inter-cluster SMEs, networks with CSR and networks with local governments. The sample used in this study was tourism SMEs in Temanggung and Semarang districts with different tourism characteristics. The study used a sample of 66 respondents and data processing using SPSS to test validity and reliability and WarpPLS 3.0 to test the research mediation model. The results showed that the cognitive social capital of one cluster, between clusters, CSR and government had a significant positive effect on knowledge sharing.

Sharing knowledge has a significant positive effect on SME performance. This means that knowledge sharing is measured using network density, network centrality, relational social capital (CSR) and one cluster social cognitive capital, between clusters, CSR and the government supporting SME performance. Innovation also has a significant positive effect on the performance of SMEs in Temanggung and Semarang District. This research contributes to policy making that will support the progress of SME tourism support with different tourism characteristics. The implication of this research is a strategy in the form of a network model as a lever factor for the progress of Tourism SME.
\end{abstract}

Keywords: knowledge sharing, innovation, SME performance

\section{INTRODUCTION}

Corporate social responsibility (CSR) has become one of the emerging topics in today's business environment. An increase in CSR perspective is due to two reasons; first is free media, global trade, and information sharing. Society requires the corporation to be more responsible towards social problems, and the government had to provide solutions to such problems [11]. Strategic Role SMEs in the structure of the Indonesian economy around $99 \%$ of business units in Indonesia are SMEs and absorb almost $97 \%$ of the Indonesian workforce [8]. SMEs have a strategic role in improving the economy in Indonesia. However, [12] explains common problems of SMEs in Indonesia are as follows lack of working capital; marketing difficulties; limited access to financial resources; lack of technological skills and management; low productivity; limited access to productive resources, particularly capital, technology, information and markets; the still low quality of institutions and organization of cooperatives; lack of business networks. Efforts are needed to foster a climate conducive to the development of SMEs. This is increasingly supported by the development of the tourism sector in the area. This research has significance and contributes to the management of SME development strategies through strengthening networks to support tourism SMEs. This research produced a model to strengthen SME networks with CSR perspective is free media, global trade, and information sharing.

This research focuses on the SME cluster industry with geographical proximity factors, so it is expected to produce efficient collaborative synergies. The aspects discussed in this study are strategies in the form of analysis of factors that are able to contribute to competitive advantage for SME tourism clusters. The model developed in this study refers to the research conducted by [6]. The similarity of this research with previous research is to use a research model developed by [6] namely Social Capital that is built with Network Density, Network Centrality, Relational Social Capital, and Cognitive Social Capital will influence the Knowledge Sharing and Performance of SMEs mediated by Innovation. However, this research differs from previous studies, previous studies only focused on the performance of SMEs on one type of cluster, this study was developed by looking at the context of the pattern of one cluster network, between clusters and their relationship with government. How CSR perspective develops in UKM with tourism appeal. Researchers develop from several previous studies [9], [14], [13], [4] which examines SME performance.

Some of the problems faced by SMEs that make it difficult to develop include human resource competencies, ability to access information, limited capital, limited technology, product quality, packaging, marketing strategies, promotion that has not been maximized and weak SME networks in the form of groups or other groups. Business networks that are formed, effectively improve business competitiveness 
H1. Social capital positively influences knowledge sharing H1a. Network density positively influence knowledge sharing

H1b. Network centrality positively influence knowledge sharing

H1c. Relational social capital positively influence knowledge sharing

H1d. Cognitive social capital positively influence knowledge sharing

H2. Knowledge sharing positively influence innovation

H3. Knowledge sharing positively influence performance

H4. Innovation positively influence performance

\section{RESULTS AND DISCUSSION}

analyze the effect of Social Capital proxied by Network Density, Network Centrality, Relational Social Capital, and Cognitive Social Capital will influence the Knowledge Sharing and Performance of SMEs mediated by Innovation. The sampling method used in this study was purposive sampling. The sample criteria in this study are SME owners, SMEs have been managed for more than 1 year. It is expected that these SMEs have better SME management with their involvement in one cluster, between clusters and with the government. The type of data in this study is primary data with data collection techniques through surveys in the form of questionnaire statements. The list of statements in the questionnaire was drawn from research conducted by [6] which was adjusted to the development of the research conducted.

Measurement of network density variables is good relationship with other enterprises in the cluster, relations among other firms in the cluster are very close, frequent communication with other enterprises in the cluster. Network centrality is enterprise is an important member among others in the cluster, enterprise plays a central role in the cluster, enterprise has established extensive relationships with surrounding firms. Relational social capital (RSC) is believe that if in trouble, other firms will try to help out, believe that if need any help, other firms are willing to help, can always rely on other members in the cluster. Cognitive social capital (CSC) is always agree with other firms on what is important for the development of the cluster, share the same ambitions and vision with other firms on the development of the cluster, enthusiastic about pursuing the collective goals and missions of the cluster. Knowledge sharing is frequently exchange important information (such as market trends) with others in the cluster, often obtain valuable information through relationships with others in the cluster, share my business experience with others in the cluster, learn a lot from others in the cluster. Innovation is firm provides new products and services before others do, our new products and services are often perceived as novelty goods by customers, our new products and services make us competitive with others. Performance is business has experienced an increase in sales compared to last year, business has experienced an increase in operating revenues compared to last year, business has experienced an increase in employees compared to last year. Measurement of these variables was developed by adding relationships between clusters and relations with government.
The results of testing the validity and reliability of research variables showed the results of all valid variables (significant value of Pearson correlation $<0.05$ ) and all reliable variables (Cronbach's Alpha value> 0.7) [1]

Table 1 Validity Test

\begin{tabular}{|c|c|c|c|c|}
\hline Variable & Item & $\begin{array}{l}\text { Sig. } \\
\text { (2 tailed) }\end{array}$ & $\begin{array}{l}\text { Pearson } \\
\text { Correlation }\end{array}$ & Note \\
\hline \multirow{8}{*}{$\begin{array}{l}\text { Network } \\
\text { Density (ND) }\end{array}$} & ND1 & 0,000 & $0,740^{* *}$ & Valid \\
\hline & ND2 & 0,000 & $0,706^{* *}$ & Valid \\
\hline & ND3 & 0,000 & $0,610^{* *}$ & Valid \\
\hline & ND4 & 0,000 & $0,673^{*}$ & Valid \\
\hline & ND5 & 0,000 & $0,753^{* *}$ & Valid \\
\hline & ND6 & 0,000 & $0,807^{* *}$ & Valid \\
\hline & ND7 & 0,000 & $0,766^{* *}$ & Valid \\
\hline & ND8 & 0,000 & $0,726^{* *}$ & Valid \\
\hline \multirow{5}{*}{$\begin{array}{l}\text { Network } \\
\text { Centrality (NC) }\end{array}$} & $\mathrm{NC1}$ & 0,000 & $0,763^{* *}$ & Valid \\
\hline & $\mathrm{NC} 2$ & 0,000 & $0,828^{* *}$ & Valid \\
\hline & $\mathrm{NC} 3$ & 0,000 & $0,680^{* *}$ & Valid \\
\hline & $\mathrm{NC} 4$ & 0,000 & $0,687^{* *}$ & Valid \\
\hline & NC5 & 0,000 & $0,623^{* *}$ & Valid \\
\hline \multirow{4}{*}{$\begin{array}{l}\text { Relational } \\
\text { Social Capital } \\
\text { (RSC) }\end{array}$} & $\mathrm{RSC1}$ & 0,000 & $0,776^{* *}$ & Valid \\
\hline & $\mathrm{RSC} 2$ & 0,000 & $0,804^{* *}$ & Valid \\
\hline & RSC3 & 0,000 & $0,776^{* *}$ & Valid \\
\hline & RSC4 & 0,000 & $0,677^{* *}$ & Valid \\
\hline \multirow{8}{*}{$\begin{array}{l}\text { Cognitive } \\
\text { Social Capital } \\
\text { (CSC) }\end{array}$} & $\mathrm{CSC} 1$ & 0,000 & $0,656^{* *}$ & Valid \\
\hline & $\mathrm{CSC} 2$ & 0,000 & $0,724^{* *}$ & Valid \\
\hline & CSC3 & 0,000 & $0,689^{* *}$ & Valid \\
\hline & $\mathrm{CSC} 4$ & 0,000 & $0,695^{* *}$ & Valid \\
\hline & CSC5 & 0,000 & $0,695^{* *}$ & Valid \\
\hline & CSC6 & 0,000 & $0,729^{* *}$ & Valid \\
\hline & $\mathrm{CSC} 7$ & 0,000 & $0,678^{* *}$ & Valid \\
\hline & CSC8 & 0,000 & $0,715^{* *}$ & Valid \\
\hline \multirow{8}{*}{$\begin{array}{l}\text { Knowledge } \\
\text { Sharing (KS) }\end{array}$} & KS1 & 0,000 & $0,734^{* *}$ & Valid \\
\hline & KS2 & 0,000 & $0,633^{* *}$ & Valid \\
\hline & KS3 & 0,000 & $0,798^{* *}$ & Valid \\
\hline & KS4 & 0,000 & $0,794^{* *}$ & Valid \\
\hline & KS5 & 0,000 & $0,733^{* *}$ & Valid \\
\hline & KS6 & 0,000 & $0,802^{* *}$ & Valid \\
\hline & KS7 & 0,000 & $0,715^{* *}$ & Valid \\
\hline & KS8 & 0,000 & $0,552^{* *}$ & Valid \\
\hline \multirow{3}{*}{ Innovation (I) } & I1 & 0,000 & $0,781^{* *}$ & Valid \\
\hline & $\mathrm{I} 2$ & 0,000 & $0,829^{* *}$ & Valid \\
\hline & $\mathrm{I} 3$ & 0,000 & $0,772^{* *}$ & Valid \\
\hline \multirow{3}{*}{ Performance $(\mathrm{P})$} & $\mathrm{P} 1$ & 0,000 & $0,869^{* *}$ & Valid \\
\hline & $\mathrm{P} 2$ & 0,000 & $0,864 * *$ & Valid \\
\hline & P3 & 0,000 & $0,845^{* *}$ & Valid \\
\hline
\end{tabular}




\section{CONCLUSION}

The model was developed based on the relationship between tourism SMEs through one-cluster SMEs networks, intercluster SMEs, networks with CSR and networks with local governments. The sample used in this study was tourism SMEs in Temanggung and Semarang Regency (Banyubiru) with different tourism characteristics. The results showed that Knowledge sharing had a positive effect on the performance of SMEs. It means that knowledge sharing measured using network density, network centrality, relational social capital (CSR) and one-cluster cognitive social capital, between clusters, CSR and government supports SMEs performance. This research contributes to policy making that will support the advancement of tourism support SMEs with different tourism characteristics. This research is different from previous research because this research develops in accordance with the Group Discussion Forum (FGD) conducted to determine the SMEs networks in 3 districts. The implication of this research is a strategy in the form of a network model as a lever factor for the progress of the Tourism SMEs.

\section{ACKNOWLEDGMENT}

This research is one of the 2nd Year Higher Education Flagship Research outcomes funded by the Directorate of Higher Education in 2019. Thank you was spoken to Kemenristek Dikti who had provided this research grant and UMMagelang LP3M who had facilitated PDUPT research activities in 2019.

\section{REFERENCES}

[1] Ghozali, I. (2018). Aplikasi Analisis Multivariate dengan Program IBM SPSS 21. Semarang: Badan Penerbit Universitas Diponegoro.

[2] Hamdi, M. (2016). UMKM Menggeliat seiring bertambahnya Daya Tarik Wisata di Jateng. Bisnis Indonesia.

[3] Ivars, M. (2010). ICT and Knowledge Management Models for Promotion of SME's Competitiveness. The International Journal of Technology, Knowledge and Society Volume 6 Number 3, http://www.TechnologyJournal.com, ISSN 1832-3669.

[4] Jamali, D., Peter Lund, T., \& Soren, J. (2017). SMEs and CSR in Developing Countries. Business \& Society Vol 56(1), 11-22.

[5] Jesus, S., Roy, A., \& Bautista, A. (2015). Micro, Small and Medium Enterprises and Social Networks in Tourism Industry in Manzanillo, Colima, Mexico. 
[10] Sholihin, M., \& Dwi, R. (2014). Analisis SEMPLS Dengan WarpPLS 3.0 Untuk Hubungan Nonlinier Dalam Penelitian Sosial dan Bisnis. Yogyakarta: Andi Publisher.

[6] Namhyun, K., \& Changsup, S. (2017). Social capital, knowledge sharing and innovation of small-and medium-sized enterprises in a tourism cluster.

[7] Ngugi, I., Johnsen, R. E., \& Erdelyi, P. (2010). Relational capabilities for value cocreation and innovation in SMEs. Journal of Small Business and Enterprise Development, 260-278.

[8] PPE, L. (2018). Penguatan 4 Pilar Daya Saing dan Inklusifitas Perekonomian Nasional. Outlook ekonomi Indonesia.

[9] Sarfraz, M., Wang, Q., Muhammad, I. A., \& Adnan, T. A. (2018). Employees' Perception of Corporate Social Responsibility Impact on Employee Outcomes: Mediating Role of Organizational Justice for Small and Medium Enterprises (SMEs). Sustainibility .
[11] Smith, N. C. (2003). Corporate Social Responsibility: Not Whether, But How? London: London Business School.

[12] Tambunan, T. (2008). SME Development in Indonesia: Do Economic Growth and Government Supports Matter? SSR N Electronic Journal. doi:10.2139/ssrn. 1218922

[13] Vazquez, D. G., \& Isabel Sanchez, H. (2012). Information on Corporate Social Responsibility and SMEs Enviromental Responsiveness: A Regional Studi. Economics\&Sociology Vol 5 No 2, 103-115.

[14] X, F., Garay, L., \& Jones, S. (2014). Sustainibility motivations and practices in small tourism enterprises. 